\title{
Role of Teachers Redesign Learning in Islamic Religious Education in Facing Industry Revolution 4.0 In-State SMA in Padangsidimpuan
}

\author{
$1^{\text {st }}$ Asfiati \\ Faculty of Tarbiyah and Teacher \\ Training \\ IAIN Padangsidimpuan \\ Padangsidimpuan, Indonesia \\ asfiatishamad72@gmail.com \\ $4^{\text {th }}$ Hamdan Hasibuan \\ Faculty of Tarbiyah and Teacher \\ Training \\ IAIN Padangsidimpuan \\ Padangsidimpuan, Indonesia
}

\author{
$2^{\text {nd }}$ Erna Ikawati \\ Faculty of Da'wah and \\ Communication \\ IAIN Padangsidimpuan \\ Padangsidimpuan, Indonesia
}

\author{
$3^{\text {rd }}$ Muhammad Aswin \\ Universitas Islam Negeri Sumatera \\ Utara \\ Medan, Indonesia
}

\begin{abstract}
This study aims to explore the role of Islamic Religious Education teachers in learning blended learning and hybrid learning. The learning process integrates traditional information technology supported by offline and online communication. Qualitative research methods, respondents are Islamic Religious Education teachers. Data collected by observation, interview, document study, analyzed by data reduction, data presentation and verification. The validity of the data triangulates. The findings show that only five Islamic religious education teachers redesigned Islamic religious education by: accessing learning material without having to be present in class. And there is no school at all that creates a special portal to provide online learning. It was concluded that Islamic religious education teachers have not played a role in redesigning learning to face the industrial revolution 4.0, and have not been able to create skills, cultivate our skills, meet people, and nurture relationships.
\end{abstract}

Keywords-Teachers Redesign Learning, Islamic Religious Education, Facing Industry Revolution 4.0

\section{INTRODUCTION}

The industrial revolution 4.0 is a national issue that must be faced. The industrial revolution 4.0 is marked by the massive development of information technology. All aspects of life are defaced digitally. Like e-learning and the rise of homeschooling schools. The industrial revolution 4.0 provides an opportunity for those who are able to follow it, and becomes a challenge for those who are unable to keep up with competitive global competition. Likewise in the world of education. So as not to run over in the conditions of the 21 st century in the face of the industrial revolution 4.0, education reorganizes itself to redesign learning.

Learning is redesigned according to human needs and change. Through redesign learning is expected to improve the quality of people's lives through competence, creativity and innovation. In reality the conditions of human activity which merged with the industrial revolution 4.0 caused problems.[1]. For this reason Islamic religious education teachers play a role in redesigning learning that responds to the industrial era 4.0. Where industry 4.0 is still being faced without reducing the values of Islam and humanity.

Islamic Religious Education teachers play a role in implementing the values of Islamic teachings so that students' artificial intelligence (AI) can be followed up on [2]. However, with the industrial era 4.0, there is a concern. Islamic Religious Education curriculum and Islamic religious education learning are not redesigned, so it is difficult to answer things that will happen in society such as: why, how, by whom, and in what settings. The curriculum and learning of Islamic Religious Education should be able to answer these questions. For this reason, Islamic Religious Education teachers play a role in collaborating between the conceptual framework of the Islamic Religious Education curriculum by providing comparisons in real life. Islamic religious education teachers play a role in implementing educational practices by providing opportunities for students to create, initiate and carry out activities in accordance with conditions in the industrial era 4.0. Islamic religious education teachers redesign knowledge and learning Islamic education so that they are useful and able to overcome solutions in the industrial era 4.0. Islamic Education Learning must be based on a solid foundation because learning and education in principle are always faced with extraordinary challenges in line with global developments [3].

With a strong foundation, the goal of Islamic religious education learning can be achieved. where can formulate and plan any learning activities that must be mastered by students so that learning is successful [4]. Islamic religious education learning seeks to redesign the picture of effective learning that indicates can be observed and measured. In this case the role of Islamic religious education teachers in formulating learning objectives must be clear and follow the industrial era 
4.0. Whereas the industrial revolution 4.0 prepares learners to have character, competence and innovation, then Islamic Religious Education should be redesigned by focusing on: [5] students with critical thinking, creative, communicative, collaborative and student selfesteem or self-confidence.

Redesigning Islamic Religious Education learning as one of the roles performed by Islamic religious education teachers in the face of the industrial revolution 4.0, the State High School (SMA) educational institution located in the Sidimpuan Education Office Branch Area that oversees 3 Districts of Padangsidimpuan City, South Tapanuli, Mandailing Natal seeks call on students and teachers of Islamic Religious Education to face the industrial revolution 4.0. For this Islamic Religious Education teachers registered in the Sidimpuan Education Office Area redesigned Islamic Religious Education learning by creating learning that fosters skills and nurtures relationships, cultivates our skills, meets people, and nurture relationships so as to build meaningfulness. Based on the background of this problem, the title of this research is: The role of the teacher redesigns the learning of Islamic Education in the face of the industrial revolution 4.0 at the State High School in Padangsidimpuan Service Branc

\section{INDUSTRIAL REVOLUTION 4.0}

\section{A. Definition of Industrial Revolution 4.0}

Industry 4.0 "originated from a project in the German government's advanced technology strategy that prioritized computerization of factories [6]. The industrial revolution was able to develop changes, in which those changes took place fast [7]. Another understanding of the industrial revolution was put forward by the Hannover Fair: Industrie 4.0" is released again in Hannover Fair in 2011 [8].

Based on the findings from the literature review, we define Industry 4.0 as follows: Industry 4.0 is a collective term for technologies and concepts of value chain organization. Within the modular structured Smart Factories of Industry 4.0, CPS monitor physical processes, create a virtual copy of the physical world and make decentralized decisions. Over the IoT, CPS communicate and cooperate with each other and humans in real time. Via the IoS, both internal and crossorganizational services are offered and utilized by participants of the value chain [9].

Based on the definition of the industrial revolution is interpreted that human activity is a race against time, so it is very much needed technological assistance so that production gives increased results. The industrial revolution 4.0 makes activities in human life more communicative and cooperation is built between human knowledge and skill.

\section{B. History of the Industrial Revolution 4.0.}

Many activities carried out by humans. The activities in question are those that provide added value and are commercially competitive through stages. In order to know the importance of the industrial revolution in human life following traces the history of the industrial revolution 4.0 .

The first industrial revolution took place at the end of the 18th century. Marked by the discovery of the first mechanical loom in 1784. At that time, the industry was introduced using water power and steam. Work equipment that initially depended on human and animal power was eventually replaced by a machine. At the beginning of the 20th century the 2.0 industrial revolution saw the introduction of mass production based on the division of labor. In the early 1970s the 3.0 industrial revolution emerged, starting with the use of electronics and information technology for production automation. The third generation industrial revolution was marked by the emergence of the first programmable logic controller (PLC), the modem 084-969. Computerbased automation systems make industrial machines no longer human-controlled. Beginning in 2018, the industrial revolution 4.0 was marked by a cyber-physical system. Now the industry is starting to touch the virtual world, in the form of human, machine and data connectivity, all of which are everywhere. This term is known as the internet of things [1].

The history of the industrial revolution 4.0 starts from the factory by striving for as much production as possible to lead to a cyber-physical system. History proves that the 4.0 industrial revolution is growing. The current industrial revolution is pushing the automation system in all processes of human activity, both from daily activities to activities that demand progress. The 4.0 industrial revolution connects millions of people across the universe in collaboration with transactions and transportation [10].

From the historical development of the industrial revolution 4.0 still needs to be done a deep understanding, where its development has not been directed because each human being and the world have different activities [11]. This happened because of the historical study of the industrial revolution 4.0 all the time still trying to new things for the sake of realizing ideas from every aspect. Likewise from the aspect of education and learning. Education as a hallmark of civilized humans should face the industrial revolution 4.0 without undermining the values of humanity and civilization. For this reason, it is important to formulate an industrial revolution from an educational standpoint so that the historical conditions of the industrial revolution 4.0 produce more useful things.

\section{Industrial Revolution in the World of Education}

In educational institutions, industrial development is faced by using the approach of Islamic science, which is based on technology. It is important to pay attention to the movement from the school to the world of work. Referring to the results of research from McKinsey in 2016 that the impact of the 4.0 industrial revolution in the next five (5) years there were 52.6 million types of jobs will experience a shift or disappear from the face of 
the earth. The results of this study give the message that: Every self who still wants to have their existence in global competition must prepare mentally and skills that have competitive advantages from others. The main way to prepare skills is to have good behavior (behavioral attitude), increase self-competence and have a literacy spirit. The preparation of self-preparation can be passed through the path of education (long life education) and self-concept through the experience of working across generations /across disciplines (experience is the best teacher) [7].

Based on the results of this study, it is necessary to redesign Islamic learning education. For this reason, there is a need for school reform, capacity building and professionalism of teachers, a dynamic curriculum, reliable facilities and infrastructure, and the latest learning technology so that the national education world can adjust to the dynamics of the times. Likewise, Islamic Education teachers can enter the workforce so they can survive in the era of the industrial revolution 4.0. For this reason, teachers must: be professional, to be able to operationalize digital learning devices, and be able to replace the human brain with computerization [12].

\section{LEARNING ISLAMIC RELIGIOUS EDUCATION}

Learning Islamic religious education is: habituation, exemplary and changes in students' mindset about the importance of the teachings of the Koran and Hadith in life. Islamic religious education learning is carried out communicatively through cooperation between students and educators. Students are required to have creativity and then the teacher directs it with a number of learning innovations. An increasing change of students is an indicator of students facing the industrial revolution 4.0. One of these indicators can provide a clear picture of the forms of behavior expected of students such as: knowing, understanding, being positive, being able to do a job and others [13].

In achieving learning objectives, educators play an active role in communicating between learning material and learners' skills. Students are expected to be able to apply each material to real life. Between expectations and reality are integrated and produce added value for the development of student creativity. Creative students are able to formulate the direction of life and life so that it produces as a guide product as one of the learning objectives. The learning objectives must be: oriented towards the interests of students rather than the interests of teachers. stated with operational verbs that refers to the results of actions that can be observed and measured the results with certain measuring devices.

\section{REDESIGN OF ISLAMIC RELIGIOUS EDUCATION LEARNING}

The learning system that was originally based on face to face directly in the classroom, is not impossible to be replaced with an integrated learning system through the internet network (online learning). In learning Islamic Education that can be redesigned are: accessing Islamic
Religious Education learning materials without having to be present in class, creating a special portal that provides free online learning learning and can be accessed by anyone, making a blueprint for "religious education learning blueprints" Islam, Islamic Religious Education teachers must have basic competencies which include, professional competencies such as academic understanding and knowledge, pedagogical competencies, namely communication, creating digital based learning programs, Senior High School is demanded to have adequate digital literacy, Islamic religious education curriculum follows the development of technology and information in the arena of the industrial revolution 4.0 in various sectors, curriculum reorientation includes new literacy such as big data, technology or coding and humanities, extracurricular activities in the form of leadership development related to Prophet Muhammad and work in deliberation and muzakaroh teams, entrepreneurship and internship are also required, Senior High School (SMA) implements $a$ hybrid / blended learning system online.

Marshall McLuhan, The Gutenberg Galaxy in his book "The Making of Typographic Man" (1962), stated that the era of the industrial revolution was marked by artificial intelligence, the era of supercomputers, genetic engineering, nanotechnology, automatic cars, innovation, and change which occurs in exponential speed.

Islamic religious education learning must be able to maintain idealism in the digital age, for that we need to redesign learning in classrooms based on 21 st century skills including: a. Inquiry and Discovery Learning. Teachers must be prepared with a variety of critical questions beyond the expectations raised by students. $b$. Student Learning Center. Learners who become the center as well as learning resources are no longer from the teacher. c. Problem Base Learning. Learners are accustomed to learning to solve problems in the field. $\mathrm{d}$. Collaborating Learning. Students are able to collaborate with their peers in learning.

\section{Methodology}

This research approach is qualitative. The research respondents were Islamic religious education teachers who actively taught at the State High Schools in the Regional Branch of the Sidimpuan Education Office totaling 114. Data collection techniques were: observation, in-depth interviews, document studies, and group discussion forums. The data analysis is: data reduction (data reduction), data display (data presentation), conclusion drawing /verification. To ensure the validity of the data researchers conduct triangulation. As for the resources of researchers and those who have expertise related to the research conducted are: Principals of state senior high schools in the regional branches of Padangsidimpuan Education Office. School Committees from state high schools in the regional branches of the Padangsidimpuan Education Office. Educational Observer, who is an expert in the field of educational technology who has the task of 
teaching in Higher Education. Head of Padangsidimpuan Education Office Branch. Youtuber, Website Developer, Blogger, Game Developer. Users of digital technology, such as E-learning, Blended Learning.

\section{RESEARCH RESULTS}

This study found the role of Islamic religious education teachers in redesigning Islamic religious education learning towards the industrial revolution 4.0 at the Sidimpuan Service Branch: had a different profile. The different profiles indicate a variety of learning activities that are mutually supportive and dynamic. The role of Islamic religious education teachers in redesigning learning Islamic religious education was found that Islamic religious education teachers who were scattered in 12 research locations compiled Learning Program Designs, Sylabus, Prota and Prosem based on the 2013 curriculum to follow all-digital learning, the internet. Islamic Religious Education teachers access Islamic religious education material from Islamic religious education portals both from the center and from religious ministries in Padangsidimpuan, South Tapanuli and Mandailing Natal Districts.

The redesign was carried out by utilizing the school website and determined the effective day to discuss materials related to the demands of the industrial revolution 4.0 .

Table 1. Redesign of learning in high schools in the Sidimpuan education office branch

\begin{tabular}{|c|c|c|c|}
\hline No & $\begin{array}{lrr}\text { Islamic religious education } \\
\text { Material High School Odd } \\
\text { Semester according } \\
\text { Curriculum } 2013\end{array}$ & Learning redesigned & Learning Redesign Conducted \\
\hline 1 & I'm Close to Allah & $\begin{array}{l}\text { Tells the experience of } \\
\text { students and arranges steps on } \\
\text { how to respond to the } \\
\text { presence of Allah. when } \\
\text { exposed to disaster, get } \\
\text { pleasure. }\end{array}$ & $\begin{array}{l}\text { students who have social media } \\
\text { accounts are assigned to upload } \\
\text { their daily activities and then } \\
\text { publish them on YouTube. } \\
\text { YouTube results are displayed } \\
\text { to students and then used as } \\
\text { teaching material }\end{array}$ \\
\hline 2 & $\begin{array}{l}\text { Muslim and Muslim dress is a } \\
\text { mirror of the personality and } \\
\text { beauty of students. }\end{array}$ & $\begin{array}{l}\text { It is advisable to sort and } \\
\text { choose Muslim clothing that is } \\
\text { in accordance with Islamic } \\
\text { sharia. }\end{array}$ & $\begin{array}{l}\text { Students are required to open } \\
\text { online sales of Muslim clothing } \\
\text { done in the student class as a } \\
\text { seller as well as a consumer. }\end{array}$ \\
\hline 3 & $\begin{array}{l}\text { Faith in Allah SWT through } \\
\text { Asmaul Husna, }\end{array}$ & $\begin{array}{l}\text { Playing IM3 about Asmaul } \\
\text { Husna }\end{array}$ & $\begin{array}{l}\text { Students form a group of } \\
\text { Qasidahan Asmaul Husna. } \\
\text { Recordings are displayed on } \\
\text { YouTube, Facebook. Students } \\
\text { make members and are } \\
\text { socialized through the } \\
\text { application }\end{array}$ \\
\hline
\end{tabular}

The role of Islamic Religion Teachers (PAI in Indonesian) in redesigning learning is supported by schools. This is proven by the school providing opportunities for PAI teachers to use internet facilities: From 12 schools found that each school has a website. The redesign of learning does not only depend on the teacher, but also on students as the center of learning. For that students are given the steps of learning before learning begins. Students are also directed to master technology and be able to access PAI learning materials. Each teacher suggests students open a personal account and create an online learning system (in the network). Students are also directed to complete assignments using internet devices and publish them through applications and educational and learning portals.

\section{CONCLUSION}

It was concluded that Islamic religious education teachers have not played a role in redesigning learning to face the industrial revolution 4.0, The Islamic religious education teachers have not been able to create skills, cultivate our skills, meet people, and nurture relationships. The Islamic religious education teachers Islamic religious education teachers must equip themselves with learning technology. Islamic religious education teachers must be able to apply electronic learning for redesigning learning.

\section{REFERENCES}

[1] Ahmad Rouzni Noor II, "Mengenal Konsep Revolusi Industri40," Detikinet, Jakarta, pp. 1-4, 2018.

[2] Asfiati, Pendekatan Humanis dalam Pengembangan Kurikulum. Bandung: Perdana Publishing, 2016.

[3] Umar, "Pengembangan Kurikulum Pendidikan Agama Islam Transformatif." Deepublish, Yogyakarta, p. h.12., 2016.

[4] S. F. Shodiq, "Revival Tujuan Pembelajaran Pendidikan Agama Islam (PAI) Di Era Revolusi 4.0,"," -Tajdid J. Pendidik. Dan Pemikir. Islam, vol. 02, no. 02, pp. 216-225, 2018.

[5] H. Triyan, "Mendikbud Siapkan 5 Langkah Strategi Hadapi Revolusi Industri 4," Okenews, Jakarta.

[6] "Industri 4.0," Wikipedia Encyclopedia Bebas. .

[7] H. Suwardana, "Revolusi Industri 4.0 Berbasis Revolusi Mental," vol. 1, no. 2, pp. 102-110, 2017. 
[8] K. Hl. WWahlster, "Industrie 4.0 Industrie 4.0: Mit dem Internet der Dinge auf dem Weg zur 4. industriellen Revolution ingenieur.de," ingenieur.de - Jobbörse und Nachrichtenportal für Ingenieure," Hannover Fair, STRUKTURWANDEL, Apr-2011.

[9] and B. O. M. Hermann, T. Pentek, "Design Principles for Industrie 4.0 Scenarios," 2016, pp. 3928-3937.

[10] Slamet Rosyadi, "Revolusi Industri 4.0: Peluang Dan Tantangan Bagi Alumni Universitas Terbuka,"," J. Public Adm. IJPA, vol. 3, no. 2, p. h.2., 2018.

[11] H. P. and W. Sutopo, "Telaah Klasifikasi Aspek Dan Arah Perkembangan Riset," J. Tek. Ind., vol. 13, no. 1, p. h.17-26, 2018.

[12] H. Putra, Pendidikan Islam dalam Sistem Pendidikan Nasional di Indonesia. Jakarta: Kencana, 2004.

[13] D. Mahfud, Pembelajaran Pendidikan Agama Islam Berbasis Multietnik. Yogyakarta: Deepublish, 2015. 